\title{
PREDICTION THE NUTRITIVE VALUE OF PRICKLY PEAR PEELS AS A NATURAL UNCONVENTIONAL FEED RESOURCE FOR FEEDING RUMINANTS FROM CHEMICAL COMPOSITION AND IN VITRO DIGESTIBILITY USING DAISY II INCUBATOR
}

\author{
Azza, M.M. Badr ${ }^{1}$; A.A. Bakr ${ }^{1}$ and M.M. El-Shinnawy ${ }^{2}$ \\ ${ }^{1}$ Regional Center for Food and Feed, Agric. Res. Center., Giza, Egypt. \\ ${ }^{2}$ Fac. of Agric., Mansoura Univ. \\ azzabadr805@yahoo.com
}

\section{SUMMARY}

$\mathrm{P}$ rickly pear peels (PPPs) was evaluated for their chemical and nutritional composition as a natural feed resource for feeding ruminants in two experiments. Each experiment consisted of three rations. Concentrate feed mixture (CFM), berseem hay (BH), rice straw (RS) and PPPs were used for formulating the experimental rations ( $60 \%$ concentrate $+40 \%$ roughage). In the first experiment $25 \%$ or $50 \%$ of RS were replaced by PPPs. In the second experiment, the inclusion rates of PPPs were instead of $25 \%$ or $50 \%$ BH. Chemical composition and in vitro digestibility using DAISY II incubator were used for nutritive value prediction. The results indicated that PPPs had lower contents of CP (5.67\%) and CF (10.63\%) while; it had higher values of NFE (69.59\%) and NSC (66.56\%) when compared with other ingredients used. Prickly pear peels had the lowest values of NDF (13.67\%); ADF (10.20\%), ADL (2.49\%), hemicellulose (3.47\%) and lignin $(0.74 \%)$ when compared with other ingredients, but had higher NDF- cell soluble ( $86.33 \%)$. The highest values of apparent dry matter digestibility (ADMD) and true dry matter digestibility (TDMD) were recorded with PPPs $(90.22 \%$ and $91.46 \%)$, respectively when compared with other ingredients. The natural detergent fiber digestibility (NDFD) was higher than that in RS and CFM while, it is lower than that in BH. The prediction parameters of nutritive values from chemical analysis for TDN\% and NEL, ME, NEM, NEG, and DE (Mcal $/ \mathrm{Lb}$ of DM) of PPPs were significantly $(\mathrm{p}<0.05)$ higher than those of other ingredients and followed by CFM. The lowest values were recorded with BH and RS. Ration (3) in which PPPs replaced 50\% of RS recorded the best values of NFE and NCF, but lowest values of ash and CF when compared with control ration and ration $25 \%$ RS with PPPs. Ration 3 had the lowest values of NDF, ADF, cellulose, hemicellulose and lignin, followed by ration (2). The highest values were recorded with control ration. The highest increase value of NDF-cell soluble $(17.45 \%$ ) was recorded with ration (3) while, the increase in ration (2) reached $9.21 \%$ when compared with control ration. The effect of inclusion different levels of PPPs instead of the same levels of RS showed significant $(<0.05)$ increase of ADMD\% with ration (3) followed by ration (2) while TDMD\% was not significantly influenced by inclusion of PPPs. In the contrarily, the NDFD\% was decreased. Ration (3) had the highest values of TDN\%, DDM\%, DMI\%, NEL, ME, NEM, NEG, DE (Mcal /Lb. of DM) and GE (MJ/Kg DM) while control ration recorded the lowest values. The highest feed cost and price of TDN unit were recorded for the control ration. The highest decreasing price of TDN unit (9.09\%) was obtained by ration (3). Inclusion of PPPs instead of $\mathrm{BH}$ decreased $\mathrm{CP} \%, \mathrm{EE} \%, \mathrm{CF} \%$ and fiber fraction $\%$ of rations 5 and 6 , while NFE\%, NSC\% and NDF-cell soluble \% were increased. Concerning, DM digestibility determination, the highest value of TDMD\% was obtained with ration 6 followed by ration 5. The predicted energy values were higher with ration 6 while it recorded the lowest value of GE. This ration also recorded the highest feeding values. Replacing PPPs instead of BH up to 50\% decreased the price of TDN unit by about $13.33 \%$. Information provided by our work introduce a package of two types of rations containing different levels of PPPs which could be used successfully, economically and nutritionally as a good unconventional ration for feeding ruminants in different purpose of production and could reduce waste disposal problems, further investigation on PPPs and its utilization as a raw material in feeding ruminants is needed.

Keywords: DAISYII incubator, feed intake, apparent and true digestibility, prickly pear peels, wheat bran and berseem hay. 


\section{INTRODUCTION}

Increasing animal protein production in Egypt depend upon the possibility of exploring and utilizing all possible and available resources of agriculture- co- products in animal feeding (El- Shinnawy and Eassawy, 2016). The processing of many fruits results in accumulation of large quantities of by -products. Proper utilization of these by-products could reduce waste disposal problems and serve as a potential new source of fats and protein for use in food and feed(Kamel and Kakuda, 2002).

In Egypt, the total area annually cultivated with prickly pear (PP) was about 14100 feddans producing about 28400 tons' fruits which calculated about 13420 tons of peels (Anonymous, 2008). Fruits of PP are recognized as an important source of vitamins for local people. The vegetable stems and fruits of PP are useful for a variety of purposes including food (fresh fruit, paste, Jam, salads and refreshing drinks) fodder (auxiliary, feed for cattle, sheep and goats) and medicinal (antidiabetic agent) and for industrial products such as alcohol, pectin's and oils (Lakshminarayana, 1980).

Peels and seeds are the waste products of the PP fruits processing industries. Prickly pear peels (PPPs) makes up about $50 \%$ of the whole fruit weight and is subsequently the major by- product while, seeds constitute about $10-15 \%$ of the edible pulp and are usually discarded as waste after extraction of the pulp. Stintzing et. al., (2000) indicated that the oil processed from the seeds constitutes 7-15\% of the whole seed weight and is characterized by high degree of instauration wherein linoleic acid is the major fatty acid (57$77.1 \%)$.

The fruits have a thick peel enclosing a delicately flavored very seedy pulp. There are few reports in literatures about the utilization of the peels of PP fruits. Badr et. al., (2017) cleared that PPPs is a source of protein $(4.75 \%)$, carbohydrates $(59.25 \%)$, calcium $(2.04 \%)$, iron $(80.35 \mathrm{mg} / \mathrm{kg})$, zinc $(37.49 \mathrm{mg} / \mathrm{kg})$, copper $(1.92 \mathrm{mg} / \mathrm{kg})$, phosphorous $(0.9 \%)$, mannan $(7.76 \%)$, betaglucan $(27.25 \%)$ and $\beta$ - carotene $(141.4 \mu \mathrm{g} / 100 \mathrm{~g})$. PPPs content of hemicellulose, cellulose and lignin were $0.5,10.92 \%$ and $1.2 \%$, respectively. Amino acid profile ensured the existence of fifteen amino acids of which seven were essentials: leucine $(0.22 \%)$, valine $(.19 \%)$, lysine $(0.11 \%)$, phenylalanine $(0.14 \%)$, threonine $(0.14 \%)$, isoleucine $(0.15 \%)$ and histidine $(0.09 \%)$. The remaining amino acids were aspartic acid $(0.28 \%)$, arginine $(0.15 \%)$, alanine $(0.19 \%)$, proline $(0.23 \%)$, glutamic acid $(0.32 \%)$, glycine $(0.18 \%)$ and serine $(0.14 \%)$. So, the chemical composition indicated that PPPs is rich (on dry matter basis) in its content especially in readily digestible carbohydrate that it's may serve as a good source of fermentable ME. Although it has been used as an animal feed its value especially for farm animals, has received little research attention.

One of the major needs within the PP industry is the development of new processed PP products as well as the fruit by products. These new functional components from prickly pear peel open new possibilities for adding value to a very ancient, but not sufficiently known, crop of the arid and semi -arid regions. The expansion of the PP cultivation in arid and semi- arid areas could be of interest for stimulating bio industries in developing countries (Terrazas et. al. ,2002).

The purpose of this study is the evaluation of the chemical composition and feeding value of PPPs as a by-product and investigating the effects of its inclusion in ruminant rations, instead of rice straw (RS) and berseem hay $(\mathrm{BH})$ from nutritional and economical points of view.

\section{MATERIAL AND METHODS}

The present study was conducted at the Laboratories of the Regional Center for Food and Feed (RCFF), Agric. Res. Center (ARC), Ministry of Agric., Giza, Egypt.

\section{Preparation of the dried powder of PPPs and feed ingredients:}

The prickly pear peels (PPPs) were collected from local market of Giza Governorate during summer season (August 2016). The peels were dried by spreading in direct sun after being chopped (about $3 \mathrm{~cm}$ length). The peels were shuffled upside- down and mixed well every day until its moisture content 
regressed to about $20 \%$. Complete drying was done by using an oven at $55^{\circ} \mathrm{C}$ for $8 \mathrm{~h}$., the dried peels and feed ingredients were grounded in a blender for $5 \mathrm{~min}$. and packed in polyethylene bags until analysis.

\section{Experiments:}

Concentrate feed mixture (CFM), berseem hay (BH), rice straw (RS) and prickly pear peels (PPPs) were used in formulation the experimental rations. Two experimental rations were formulated to determine the chemical composition and estimate the feeding values of PPPs. Each experiment consisted of three rations as follows:

Experiment (1): Three complete rations (about $12 \% \mathrm{cp}$ ) were formulated for fatting animals in the first stage. In this experiment $25 \%$ and $50 \%$ of RS were replaced by PPPs as follows:

Ration (1): $60 \% \mathrm{CFM}+40 \% \mathrm{RS}$ (control ration).

Ration (2): $60 \%$ CFM+30\%RS+10\%PPPs.

Ration (3) $60 \% \mathrm{CFM}+20 \% \mathrm{RS}+20 \%$ PPPs.

Experiment (2): Three complete rations (about $17 \%$ crude protein) were used in this experiment for lactating cattle. Berseem hay was replaced with $25 \%$ and $50 \%$ by the same levels of PPPs in rations 5 and 6 , respectively as follows:

Ration (4): 60\% CFM+40\% BH (control ration).

Ration (5): $60 \% \mathrm{CFM}+30 \% \mathrm{BH}+10 \%$ PPPs.

Ration (6) $60 \% \mathrm{CFM}+20 \% \mathrm{BH}+20 \%$ PPPs.

Representative samples of feed ingredients and experimental rations were taken for proximate analysis according to the procedures of AOAC (2002). Neutral detergent fiber (NDF), acid detergent fiber (ADF) and acid detergent lignin (ADL) contents of feed ingredients and experimental rations were determined according to Van Soest et al. (1991). Cellulose (CEL.) and hemicellulose (HEM.) contents were calculated respectively, by subtracting ADL from ADF and ADF from NDF.

In- vitro digestion with Ankom Daisy ${ }^{\text {II }}$ incubator method: In vitro digestibility's of feed ingredients and experimental rations were done by using the Ankom Daisy ${ }^{\mathrm{II}}$ incubator procedure. The procedure followed is described in detail by Goeser and Combs (2009). Tilley and Terry technique (1963) was used for the determination of apparent dry matter digestibility (ADMD). True in vitro DM digestibility (TDD) can be determined by measuring the neutral detergent fiber (NDF) in the residue from the incubation with rumen inoculum and buffer. Neutral detergent fiber digestibility (NDFD) was determined with Ankom Daisy ${ }^{\mathrm{II}}$ incubator procedure. In -Vitro true digestibility and NDFD were calculated according to Ankom daisy ${ }^{\text {II }}$ incubator method:

\section{Prediction of energy estimation by equations for feed evaluation using chemical components of feed:}

Prediction of energy availability from laboratory analyses usually requires specific equations for each type of feed. The accuracy of energy predictions is a function of the accuracy of laboratory analyses and the accuracy of the animal experimentation used to develop the prediction equation Available energy and digestibility cannot be measured in the laboratory and is estimated from chemical composition. Most energy values are predicted from fiber analyses because fiber is negatively related to the animal's ability to digest and use nutrients in the feed according to NRC, (2001).

Equations:

$\mathrm{GE}=$ Growth Energy $(\mathrm{MJ} / \mathrm{Kg} \mathrm{DM})=0.0226 * \mathrm{CP}+0.0407 * \mathrm{EE}+0.0192 * \mathrm{CF}+0.0177 * \mathrm{NFC}$ according to Maff (1975)

DDM= Dry Matter Digestibility\%= 88.9- $(0.779 *$ ADF\% $)$.

DMI $=$ Dry Matter Intake $=120 /$ NDF\%.

$\mathrm{DE}=$ Digestible Energy $(\mathrm{Mcal} / \mathrm{Lb}$. of DM $)=(0.04409 * \mathrm{TDN}) / 2.204$.

$\mathrm{TDN}=$ Total Digestible Nutrients $(100 \% \mathrm{DM})=82.38-(0.7515 * \% \mathrm{ADF})$.

$\mathrm{ME}=$ Metabolizable Energy $(\mathrm{Mcal} / \mathrm{Lb}$. of DM $)=(1.01 *(0.04409 * \mathrm{TDN}))-0.45) / 2.204$.

$\mathrm{NEM}=$ Net Energy Maintenance $(\mathrm{Mcal} / \mathrm{Lb}$. of DM $)=(1.37 * \mathrm{ME})-\left(0.138 * \mathrm{ME}^{2}\right)-\left(0.105 * \mathrm{ME}^{3}\right)-$ $1.12 / 2.204$.

$\mathrm{NEG}=$ Net Energy Growth $(\mathrm{Mcal} / \mathrm{Lb}$. of DM $\left.)=(1.42 * \mathrm{ME})-\left(0.174 * \mathrm{ME}^{2}\right)-\left(0.0122 * \mathrm{ME}^{3}\right)-1.65\right) / 2.204$. 
$\mathrm{NEL}=$ Net Energy of Lactation $(\mathrm{Mcal} / \mathrm{Lb}$. of DM $)=((0.0245 * \mathrm{TDN})-0.12) / 2.204)$.

$\mathrm{NSC}=$ Non- Structure Carbohydrate $=100-(\mathrm{NDF} \%+\mathrm{CP} \%+\mathrm{EE} \%+\mathrm{ASH} \%)$.

\section{Economic study:}

According to market prices of different feed ingredients used for formulating rations, the feed cost and the price of TDN unit of each experimental ration was calculated. The prices of feed ingredients in Egyptian pound (LE / ton) were 4000 concentrate feed mixture (CFM), 1800 berseem hay (BH), 600 rice straw (RS) and 200 PPPs according to price (2017).

\section{Statistical analysis:}

Data were analyzed according to the statistical analysis system user guide, (SAS 1998). Separating among means was carried out by using Duncan multiple test (1955).

\section{RESULTS AND DISCUSION}

\section{The chemical compositions of feed ingredients:}

Chemical compositions of feed ingredients used for formulating the experimental rations are presented in Table (1). The results showed that chemical composition of berseem hay and CFM were within the corresponding ranges reported by El-Shinnawy et. al., (2011 a and b). The data for chemical composition of PPPs were in agreement with those obtained by (Gregory and Felker, 1992, Felker, 1995; Lopez et. al., 2001; El-Said et al., 2011 and Badr et al., 2017). It is interest to note that PPPs had lower contents of CP (5.67\%)and CF (10-69\%) while, it had higher values of NFE (69.59\%) and NSC (66.56\%) when compared with other ingredients used. Comparable values of CP content have been reported for PPPs grown on poor soils (De Kock, 1980; Flachowsky and Yami, 1985; and Hanselka and Paschal, 1990). Data of fiber fraction values are shown in Table (1). The results indicated that PPPs had the lowest values of NDF (13.67\%); ADF (10-20\%); ADL (2.49\%); hemi. (3.47\%), cell (7.71\%) and lignin (0.74\%)when compared with another ingredient but higher nonstructural carbohydrate, NDF-cell soluble (86.33\%). In the contrary of PPPs, RS contained higher NDF, ADF and ADL, cellulose, hemicelluloses and lignin when compared with other ingredients. The NDF content of PPPs obtained in this study is higher than that recorded by Amare et al. (2009) while, the ADF content is lower. In- vitro Daisy ${ }^{\mathrm{II}}$ incubator analysis of appeared dry matter digestibility (ADMD) and True dry matter digestibility TDMD) are shown in Table (2). The results indicated that the highest values of ADMD and TDMD were recorded with PPPs (90.22\% and 91.46\%), respectively when compared with other ingredients. The neutral detergent fiber digestibility (NDFD) was higher than that in rice straw and concentrate mixture while, it is lower than that in berseem hay. Predicting the energy values of ingredients based on chemical composition are illustrated in Table (2). The results indicated that the prediction values of DDM $80.95 \%$., DMI $8.78 \%$ and TDN $74.72 \%$ of PPPs where significantly $(p<0.05)$ higher than that of others, followed by concentrate mixture. The lowest values were recorded with berseem hay and rice straw. The prediction parameters from chemical analysis for \%TDN, ME, NEM, NEG and DE (Mcal/Lb of dry matter in Table (2) followed the same trend. The significant $(p<0.01)$ highest values were recorded with PPPs followed by concentrate mixture and berseem hay but the lowest values were in rice straw.

\section{Experimental (1): Inclusion two levels of PPPs instead of the same levels of $R S$ in ruminant rations:}

Table (3) presented the chemical compositions and fiber fractions of the three experimental rations. The results indicated that ration 3 which contained 20\% PPPs recorded the higher values of NFE and NCF, but lower values of ash and CF when compared with the other experimental rations. The obtained results are in agreement with those recorded by Ben Salem et. al., (1996) and Mengistu (2001) who reported that PPPs is rich in readily available carbohydrates which could serve as a source of energy for animals. There are no noticeable differences in $\mathrm{OM}, \mathrm{CP}$ and $\mathrm{EE}$ among the three rations. The results of $\mathrm{CP}$ content were in accordance with that obtained by Felker., (1995) The similarity of CP content in the three rations may be attributed to the similar CP content of RS and PPP,s 
Results presented in Table (3) show that replacement 25\% of RS with PPPs (ration 2) decreased NDF, $\mathrm{ADF}$, cellulose, hemi and lignin when compared with ration 1 (control ration). The highest values of decrease were recorded with ration 3 (containing 20\% PPPs) when compared with control ration or ration 2 . The highest increase value of NDF- cell soluble (14.86\%) was recorded with ration (3) while increase in $\mathrm{NDF}$, cell soluble in ration 2 reached $8.43 \%$ when compared with control ration. The low fiber content in ration 2 and 3 which containing PPPs were in comparable with those obtained by Tikabo et al. (2006). Data in Table (4) indicated significant ( $\mathrm{p}<0.01)$ increase of ADMD\% with ration 3 followed by ration 2 but, the lowest value was recorded with control ration. The TDMD\% was not significantly influenced by inclusion of PPPs while, NDFD\% was decreased with ration 3 when compared with other rations.

Predictions of energy by equations for rations of experiment (1) are presented in Table (4). The results indicated that ration 3 had higher values of TDN\%, NEL, ME, NEG, DE, DDM, DMI and GE\% than that of other rations. Control ration recorded the lowest values while, the values of ration (2) were intermediate. The feed cost and price of TDN unit of each experimental ration are presented in Table (5). The results indicated that the highest cost of TDN units was recorded for the control ration $(60 \%$ CFM $+40 \%$ RS), while the lowest cost was observed with ration $3(60 \% \mathrm{CFM}+20 \% \mathrm{RS}+20 \% \mathrm{PPPs})$. The highest \% of decreasing price of TDN units $(9.09 \%)$ was recorded for ration 3.

\section{Experiment (2): Inclusion two of PPPs instead of the same levels of BH. in ruminant rations.}

The effect of inclusion of PPPs instead of BH on chemical composition and fiber fraction in experiment (2) are presented in Table (6).

Replaces BH by PPP,s in basal ration by 0,10 and $20 \%$ on dry matter basis decreased CP, EE, CF and fiber fraction of rations 5 and 6 while $\mathrm{BH}$ and PPP,s increased NFE\%, NSC\% and NDF-cell soluble. The highest values were recorded with ration 6 while the lowest values were obtained with control ration. Data in Table (7) indicated the results of DM digestibility determination by In-Vitro Daisy incubator. The highest value of TDMD\% was obtained with ration 6 , followed with ration 5 . There were no significant differences among the three rations concerning ADMD\% and NDFD\%.

Predicted energy of rations used in experiment (2) from chemical composition is indicated on Table (7). The predicted energy values of ration (6) were $0.72,1.19,0.76,2.19$ and 1.39 (Mcal/ Lb DM) for NEL, ME, NEM, NEG and DE, respectively. These values are higher than those obtained by ration (5) and control. The lowest value of GE was recorded for ration 6 . Table (7) showed the predicted feeding values of rations used in experiment 2. Ration 6 recorded the highest values of TDN, DDM and DMI\%. Concerning DMI, the present results are in good agreement with those of Azocar and Rojo (1991) who found that inclusion PPPs in rations increased DMI\%.

From the economical point of view (Table 8) the lowest price of TDN unit was recorded with ration 6 followed by ration 5. The decreasing (Table 8) percent in the price of TDN unit reached 13-33\% with ration 6 than that of control. This experiment cleared that replacing PPPs instead of BH up to 50\% decreased the feed cost by about $11.43 \%$. This decrease in feed cost may be due to that PPPs is a cheaper by product than berseem hay.

\section{CONCLUSION}

This investigation show the potential value of PPPs as a good natural source of energy and nutritive components. Ration $3(60 \% \mathrm{FM}+20 \% \mathrm{RS}+20 \% \mathrm{PPPs}$.) and ration $6(60 \% \mathrm{FM}+20 \% \mathrm{BH}+20 \% \mathrm{PPPs}$.) appear to be promising package from the nutritional and economical point of view and introduce two complete rations for different purposes of productions for dry season feeding systems that could enhance productivity of livestock. The results are also important for industrial utilization of the major by - product of the fruit. However, further chemical and nutritional evaluations are needed and more work is required for the application of PPPs in In -vivo trials for feeding ruminants. 


\section{Badr et al.}

\section{REFERENCES}

AOAC (2002): Official Methods of Analysis of the Association of Official Analytical Chemists, 17th ed. Gaithersburg, Maryland, USA.

Amare D, S Melaku and G Berhane (2009): Supplementation of iso nitrogenous oil seed cakes in cactus (Opuntia ficus-indica)-tef straw (Eragrostis tef) based feeding of Tigray Highland sheep, Anim. Feed Sci. Technol., 148 (2-4), 214-226.

Anonymous (2008): Annual report of statistical analysis section. Economic research institute. Agriculture research. center. Ministry of Agriculture.

Azócar P and Rojo H (1991) Uso de cladodios de tuna (Opuntia ficus-indica) como suplemento forrajero estival de cabras en lactancia en reemplazo de heno de alfalfa. Avances en Producción Animal, Vol. 16, pp. 173-182.

Badr, S. E. A.; A.A. bakr; Gihan M. El-moghazy and O. A. Wahdan (2017). Anticancer activity and hypolipidemic effect of methanolic and ethanolic prickly pear cactus peel extracts. Egypt. Nut. Society Issue. The first International conference of nutrition, Hurghada, April.

Ben Salem, H.; A., Nefzaoui; and L., Ben Salem (2002a). Supplementing spineless cactus (Opuntia ficusindica $\mathrm{f}$. inermis) based diets with urea treated straw or oldman saltbush (Atriplex nummularia $\mathrm{L}$ ). Effects on intake, digestion and sheep growth. J. Agric. Sci. 138, 85-92.

Ben Salem, H., Nefzaoui, A., Abdouli, H. and. Orskov, E.R., (1996). Effects of increasing level of spinelesscactus (Opuntia ficus-indica var. inermis) on intake and digestion by sheep given straw-based diets. Anim. Sci. 62: 293-299.

Duncan, D.B. (1955). Multiple range and Multiple F test. J. Biometrics. 11:1.

De Kock, G.C., (1980). Drought resistant fodder shrub crops in south Africa. In: Le Houerou, H.N. (ed.) Browse in Africa: The current state of knowledge. ILCA, Ethiopia. pp. 109-114.

El- Shinnawy, A. M. and M. M. T. Eassawy (2016). Improving potato vine utilization by sheep using biocem treatment. J. Animal and poultry prod., Mansoura Univ.m vol. 7(9):323-330.

El- Shinnawy, A. M., T.M.EL. Afifi, Fatma, M. Salman and M.M.EL. Shinnawy (2011a). Using simple technologies for improving the nutritive value and proper utilization of cabbage wastes as ruminant feed. The $4^{\text {th }}$ Scientific conference of Animal Wealth Research Conf. in Middle East and North Africa, 475-490.

El- Shinnawy, M.M.; Emara; H.F.A. Motawe; Fatma, M. Salman and A. M.El. Shinnawy (2011b). Effect of two kinds of bacteria inoculants on preservation and nutritive values of urine broad bean silages compared with clover hay. The $4{ }^{\text {th }}$ Scientific conference of animal Welth Research Conf. in the Middle East and North Africa.

El-Said, N.M.; A.I. Nagib; Z. A. Rahman and S. F. Deraz (2011). Prickly pear \{Opuntia ficus. Indica (L)mill \} peels: Chemical composition, nutritional value and protective effects on liver and kidney functions and cholesterol in rats. Functional plant Science and Biotechnology, Global science books.

Felker, P. (1995): Forage and fodder production and utilization. In: G. Barbera, P., Inglese and E. PimientaBarrios (eds.). Agro-ecology, cultivation and uses of cactus pear. FAO Plant Production and Protection Paper 132. Rome. pp.144-154.

Flachowsky, G and A., Yami, (1985). Composition, digestibility and feed intake of Opuntia by Ogaden Sheep. Archiv-für-Tierernahrung. 35, 599-606. (Abstract).

Goeser, J. P. and D. K. Combs, (2009): An alternative method to assess 24-h ruminal in vitro neutral detergent fiber digestibility. J. Dairy Sci. 92:3833-3841.

Goeser, J. P. and D. K. Combs, (2009): An alternative method to assess 24-h ruminal in vitro neutral detergent fiber digestibility. J. Dairy Sci. 92:3833-3841.

Gregory, R.A. and Felker, P., (1992). Crude protein and phosphorus contents of eight contrasting Opuntia forage clones. Journal of Arid Environment. 22, 323-331.

Hanselka, C.W. and J.C., Paschal, (1990): Prickly pear cactus: an important rangeland resource. Progress report. Texas agricultural experiment station. Beef cattle research in Texas. (Abstract). Hanselka, C.W. 
and J.C. Paschal. 1991. Prickly pear cactus: an important rangeland resource. In: Progress Report, pp. 141-143. Texas Agr. Exp. Sta., U.S.A.

Kamel B.S., and y. Kakuda (2002). Fatty acids in fruits and fruits products. In: chow CK, (ED.) fatty acids in food and their health Implication ( ${ }^{\text {nd }}$ Edn.), Mar-cel Dekker, New Yourk.Pp239-270.

Lakshminarayana (1980). Sapodilla and prickly pear. In: Nagy S. Shaw PE (Eds.) Tropical and subtropical fruits. Composition properties and uses. AVI. West port. CT:415-44.

López, G.J.J., R.J.M. Fuentesand and R.A., Rodríguez (2001). Production and use of Opuntia as forage in northern Mexico. In: Mondragon, C. and Gonzalez, S. (eds.). Cactus (Opuntia spp.) as forage. FAO Plant Production and Protection Paper, 169. Rome. pp. 29-36.

Maff, 1975. Energy allowances and feeding systems for ruminants. UK Ministry of agriculture. Fisheries and food. Technical Bulletin No. 33.

Mengistu, W. (2001). Prickly pear cactus (Opuntia ficus-indica) as feed to ruminants. MSc Thesis presented to Swedish University of Agricultural Sciences, Uppsala, Sweden, and 88p.

N.R.C. (2001). Nutrient Requirement of dairy cattle $\left(7^{\text {th }}\right.$ Rev. Ed). National Academy Pres. Washington, D.C.

SAS. (1998). JMP User's Guide, Version 3.1. SAS Institute Inc., N.C.

Stintzing; FC; A. Schieber and R. Carle (2000). Cactus pear, a promising component of functional food Obst- Gemils and Kartoffeluerarheitung 85:40-47.

Terrazas, J. J.; RI. Basurrn; J. C. Montadez- Saeuz; M.I. Agular; R. Nega and J. C. Contreras- Esquivel (2002). Pricly pear (Opuntia ficus- Indica) peels as a new desert fiber. Preparation and partial characterization. In: Annual Meeting and Food. Expo Anaheim, CA, California: 114 PP.

Tikabo G, M.; Solomon and Y. Alemu (2006). Effect of wilting of cactus pear (Opuntia ficus-indica) on feedutilization in sheep. Tropical Science, Volume 46, pp. 37-40.

Tilley JM A and RA. A. Terry (1963). Two stage technique for the in vitro digestion of forage crops. J. Br. Grassl Soc. 18:104-111.

Van Soest, P.J.; J.B., Robertson and B.A., Lewis; (1991): Methods of dietary fiber, neutral detergent fiber and non-starch polysaccharide in relation to animal nutrition. J. Dairy Sci.74, 35833597. 


\title{
التببؤ بالقيمة الغذائية لقشور التين الثوكى كمصدر غذائى طبيعى غير تقليدى لتغذية المجترات من

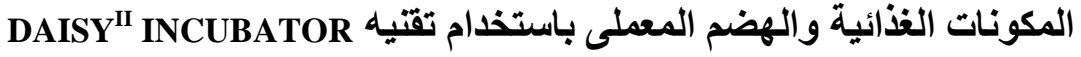

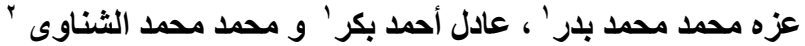

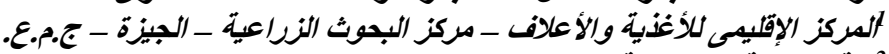 \\ 2حلية الزيراعة - جامعسة المنصورة.
}

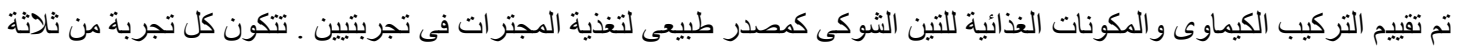

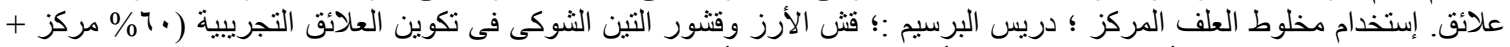

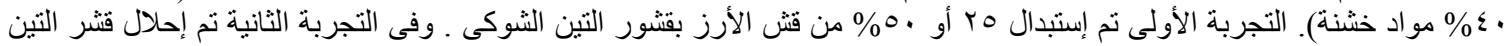

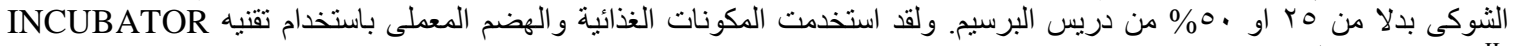
DAISY

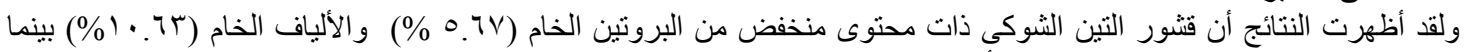

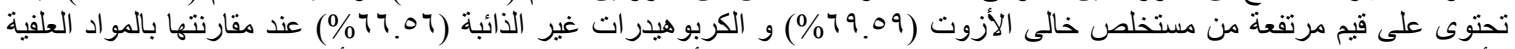

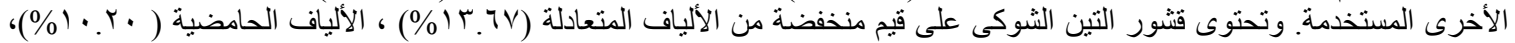

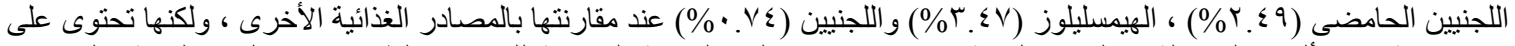

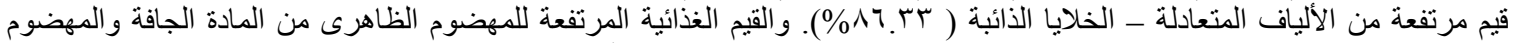

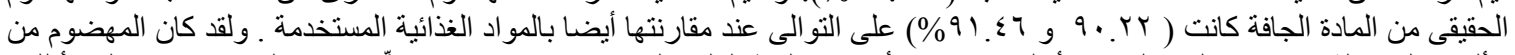

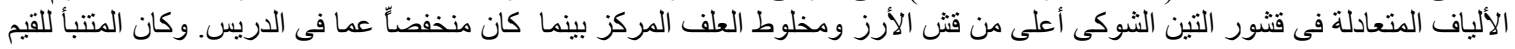

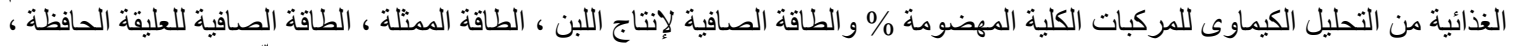

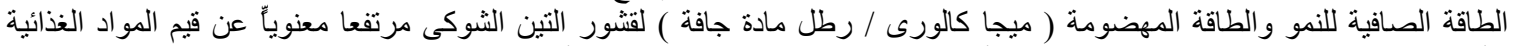

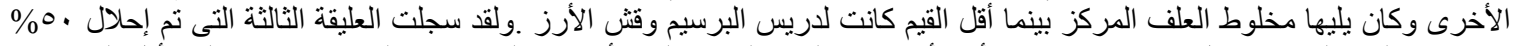

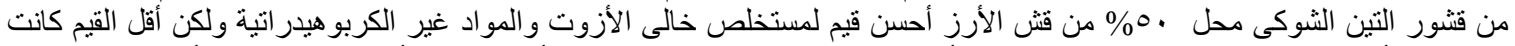

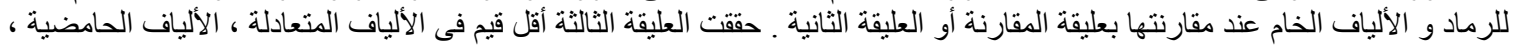

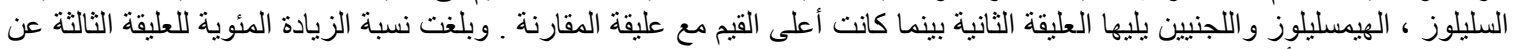

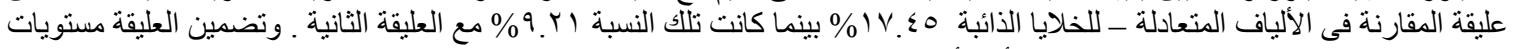

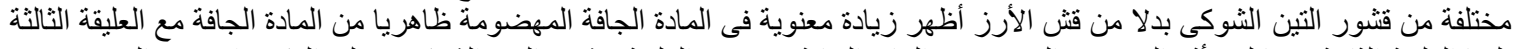

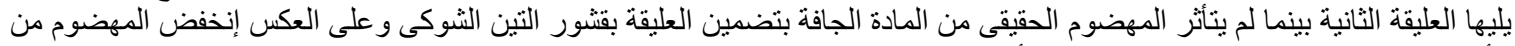

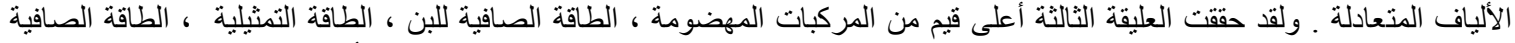

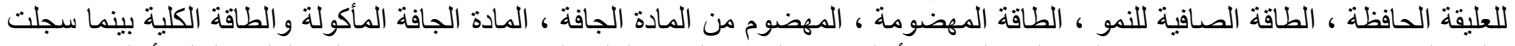

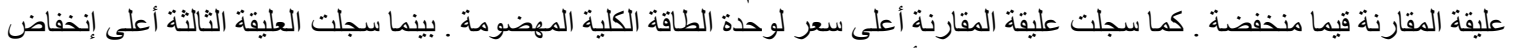

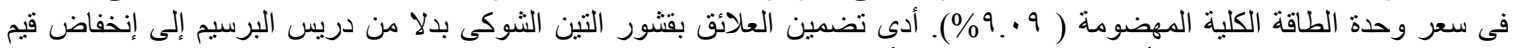

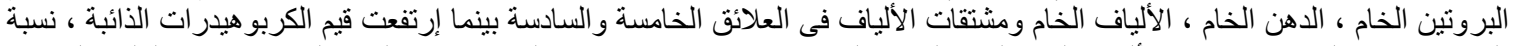

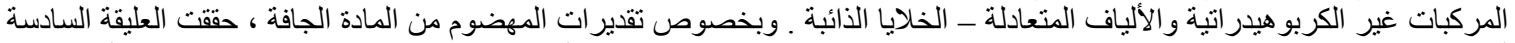

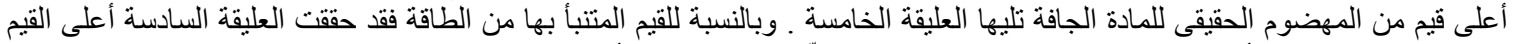

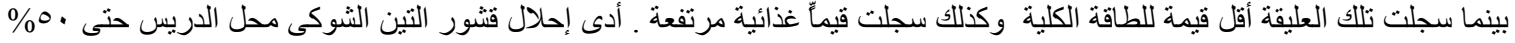

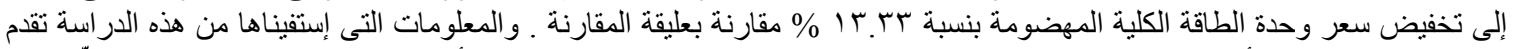

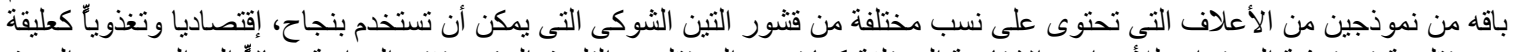

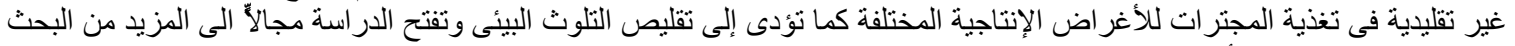

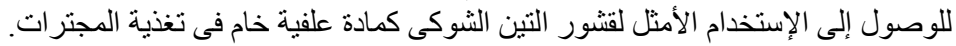


Table (1): Chemical composition and fiber fraction of feed ingredients used for formulating the experimental rations.

\begin{tabular}{lccccc}
\hline \multicolumn{1}{c}{ Ingredient } & $\begin{array}{c}\text { concentrate } \\
\text { feed } \\
\text { mixture } \\
\text { (CMF) }\end{array}$ & $\begin{array}{c}\text { Rice } \\
\text { straw }\end{array}$ & Berseem hay & prickly pear peels & SE \pm \\
& 94.34 & 94.71 & 94.44 & & \\
\hline Dry matter (DM)\% & & & & 92.21 & \\
Composition on dry matter, \% & 93.24 & 80.99 & 88.15 & 89.37 \\
Organic matter (OM) & 6.76 & 19.01 & 11.85 & 10.63 \\
Crude ash & 16.91 & 5.42 & 18.81 & 5.67 & \\
Crude Protein (CP) & 4.23 & 1.19 & 2.27 & 3.47 & \\
Ether extract (EE) & 13 & 32.38 & 29.42 & 10.64 & \\
Crude fiber (CF) & 59.1 & 42 & 37.65 & 69.59 & \\
Nitrogen free extract (NFE) & 40.98 & 6 & 31.38 & 66.56 & \\
Non-structure carbohydrate (NSC) & & & & & \\
Fiber fraction analysis, \% & $31.12 \mathrm{c}$ & $68.38 \mathrm{a}$ & $35.69 \mathrm{~b}$ & $13.67 \mathrm{~d}$ & 0.26 \\
NDF & $15.25 \mathrm{c}$ & $49.84 \mathrm{a}$ & $30.22 \mathrm{~b}$ & $10.2 \mathrm{~d}$ & 0.16 \\
ADF & $5.66 \mathrm{c}$ & $10.7 \mathrm{a}$ & $6.83 \mathrm{~b}$ & $2.49 \mathrm{~d}$ & 0.09 \\
ADL & $0.623 \mathrm{c}$ & $1.51 \mathrm{~b}$ & $1.547 \mathrm{~b}$ & $1.75 \mathrm{a}$ & 0.01 \\
AIA & $15.8 \mathrm{~b}$ & $18.56 \mathrm{a}$ & $5.47 \mathrm{c}$ & $3.47 \mathrm{~d}$ & 0.14 \\
Hemicelluloses & $9.59 \mathrm{c}$ & $39.14 \mathrm{a}$ & $32.39 \mathrm{~b}$ & $7.71 \mathrm{~d}$ & 0.12 \\
Cellulose & $3.5 \mathrm{c}$ & $8.01 \mathrm{a}$ & $5.4 \mathrm{~b}$ & $0.74 \mathrm{~d}$ & 0.1 \\
Lignin & $68.88 \mathrm{~b}$ & $31.62 \mathrm{~d}$ & $64.31 \mathrm{c}$ & $86.33 \mathrm{a}$ & 0.26 \\
NDF-cell soluble & & & & \\
\hline
\end{tabular}

$a, b, c$ and $d$ means within the same raw with different superscripts are significantly different at $(p<0.05)$

* CFM consists of $35 \%$ uncorrected cotton seed meal, $30 \%$ wheat brain, $22 \%$ yellow corn, $7 \%$ rice brain,

$3 \%$ molasses, $2 \%$ lime-stone and $1 \%$ common salt.

Table (2): Dry matter digestibility using In-Vitro Daisy ${ }^{\mathrm{II}}$ incubator and predicting energy and feeding values of ingredients based on chemical analysis.

\begin{tabular}{|c|c|c|c|c|c|}
\hline Ingredient & $\begin{array}{c}\text { Rice straw } \\
\text { (RS) }\end{array}$ & $\begin{array}{l}\text { concentrate } \\
\text { feed mixture } \\
\left.(\mathrm{CMF})\right|^{*}\end{array}$ & $\begin{array}{l}\text { Berseem hay } \\
\text { (BH) }\end{array}$ & $\begin{array}{c}\text { prickly pear } \\
\text { peels } \\
\text { (PPPs) }\end{array}$ & SE \pm \\
\hline \multicolumn{6}{|l|}{ In -vitro daisy analysis: } \\
\hline $\mathrm{ADMD}_{\mathrm{IV}} \%$ & $45.43_{\mathrm{c}}$ & $60.25_{\mathrm{b}}$ & $59.52_{\mathrm{b}}$ & $90.22_{\mathrm{a}}$ & 0.57 \\
\hline $\mathrm{TDMD}_{\mathrm{IV}} \%$ & $65.12_{\mathrm{c}}$ & $79.68_{\mathrm{b}}$ & $80.41_{b}$ & $91.46_{a}$ & 0.46 \\
\hline $\mathrm{NDFD}_{\mathrm{IV}} \%$ & $70.39_{\mathrm{bc}}$ & $67.75_{\mathrm{c}}$ & $75.59_{\mathrm{a}}$ & $72.23_{\mathrm{ab}}$ & 1.02 \\
\hline \multicolumn{6}{|l|}{ Predicted energy: } \\
\hline NEL (Mcal/ Lb. of DM) & $1.05_{\mathrm{d}}$ & $1.68_{\mathrm{b}}$ & $1.41_{\mathrm{c}}$ & $1.78_{\mathrm{a}}$ & 0.02 \\
\hline ME (Mcal/ Lb. of DM) & $0.70_{\mathrm{d}}$ & $1.23_{\mathrm{b}}$ & $1.00_{\mathrm{c}}$ & $1.31_{\mathrm{a}}$ & 0.02 \\
\hline NEM (Mcal/ Lb. of DM) & $0.35_{\mathrm{d}}$ & $0.77_{\mathrm{b}}$ & $0.62_{\mathrm{c}}$ & $0.82_{\mathrm{a}}$ & 0.00 \\
\hline NEG (Mcal/ Lb. of DM) & $0.16_{d}$ & $0.71_{\mathrm{b}}$ & $0.49_{c}$ & $0.78_{\mathrm{a}}$ & 0.00 \\
\hline DE (Mcal/ Lb. of DM) & $0.90_{\mathrm{d}}$ & $1.42_{\mathrm{b}}$ & $1.19_{\mathrm{c}}$ & $1.50_{\mathrm{a}}^{\mathrm{a}}$ & 0.00 \\
\hline GE $(\mathrm{MJ} / \mathrm{Kg} \mathrm{DM})$ & $1.54_{\mathrm{c}}$ & $1.85_{\mathrm{a}}^{\circ}$ & $1.75_{\mathrm{b}}$ & $1.71_{\mathrm{b}}$ & 1.06 \\
\hline \multicolumn{6}{|l|}{ Predicted Feeding values\%: } \\
\hline TDN \% & $44.93_{\mathrm{d}}$ & $70.92_{b}$ & $59.67_{\mathrm{c}}$ & $74.72_{\mathrm{a}}$ & 0.00885 \\
\hline DDM \% & $50.07_{\mathrm{d}}$ & $77.02_{\mathrm{b}}$ & $65.36_{\mathrm{c}}$ & $80.95_{a}$ & 0.0082 \\
\hline DMI \% & $1.75_{\mathrm{c}}$ & $3.86_{\mathrm{b}}$ & $3.36_{\mathrm{b}}$ & $8.78_{\mathrm{a}}$ & 0.00 \\
\hline
\end{tabular}


Table (3): Chemical composition and fiber fraction of rations used in experiment (1) (inclusion two levels of PPPs instead of the same levels of rice straw).

\begin{tabular}{lcccr}
\hline \multirow{2}{*}{ Ingredients } & \multicolumn{3}{c}{ Experimental rations } & SE \pm \\
\cline { 2 - 4 } & Ration 1 & Ration 2 & Ration 3 & \\
\hline DM\% & 94.49 & 94.16 & 93.99 & \\
composition on dry matter \% & & & & \\
Organic matter (OM) & 88.33 & 89.37 & 90.01 & \\
Ash & 11.67 & 10.63 & 9.99 & \\
Crude Protein (CP) & 12.3 & 12.34 & 12.39 & \\
Ether extract (EE) & 4.07 & 3.47 & 3.25 & \\
Crude fiber (CF) & 20.77 & 18.58 & 16.44 & \\
Nitrogen free extract (NFE) & 51.19 & 54.98 & 57.93 & \\
Non-structure carbohydrate (NSC) & 30.40 & 37.38 & 43.01 & \\
Fiber fraction analysis\%: & & & & \\
NDF & $41.56_{\mathrm{a}}$ & $36.18_{\mathrm{b}}$ & $31.36_{\mathrm{c}}$ & 0.22 \\
ADF & $23.52_{\mathrm{a}}$ & $20.42_{\mathrm{b}}$ & $17.81_{\mathrm{c}}$ & 0.16 \\
ADL & $4.58_{\mathrm{a}}$ & $4.31_{\mathrm{a}}$ & $4.26_{\mathrm{a}}$ & 0.26 \\
AIA & $0.86_{\mathrm{c}}$ & $1.44_{\mathrm{b}}$ & $1.61_{\mathrm{c}}$ & 0.19 \\
Hemicelluloses & $18.04_{\mathrm{a}}$ & $15.76_{\mathrm{b}}$ & $13.55_{\mathrm{c}}$ & 0.06 \\
Cellulose & $18.94_{\mathrm{a}}$ & $16.11_{\mathrm{b}}$ & $13.55_{\mathrm{c}}$ & 0.099 \\
Lignin & $3.72_{\mathrm{a}}$ & $2.87_{\mathrm{ab}}$ & $2.65_{\mathrm{b}}$ & 0.26 \\
NDF-cell soluble & $58.44_{\mathrm{c}}$ & $63.82_{\mathrm{b}}$ & $68.64_{\mathrm{a}}$ & 0.22 \\
\hline
\end{tabular}

$a, b, c$ and $d$ means within the same raw with different superscripts are significantly different at $(p<0.05)$.

Ration (1): Control $60 \%$ CFM $+40 \%$ RS.

Ration (2): $60 \%$ CFM+30\% RS+10\% PPPs.

Ration (3): $60 \%$ CFM+20\% RS+20\% PPPs.

Table (4): Dry matter digestibility determination using In-Vitro Daisy ${ }^{\mathrm{II}}$ incubator and predicting energy and feeding values of rations used in experiment (1) (inclusion two levels of PPPs instead of the same levels of rice straw).

\begin{tabular}{|c|c|c|c|c|}
\hline \multirow[b]{2}{*}{ Ingredients } & \multicolumn{3}{|c|}{ Experimental rations } & \multirow[b]{2}{*}{$\mathrm{SE} \pm$} \\
\hline & Ration 1 & Ration 2 & Ration 3 & \\
\hline \multicolumn{5}{|l|}{ In -vitro daisy analysis: } \\
\hline $\mathrm{ADMD}_{\mathrm{IV}} \%$ & $56.78_{a}$ & $60.46_{a}$ & $63.3_{\mathrm{a}}$ & 2.15 \\
\hline TDMD $_{\text {IV }} \%$ & $68.27 \mathrm{a}$ & $67.57_{\mathrm{a}}$ & $69.66_{a}$ & 1.89 \\
\hline $\mathrm{NDFD}_{\text {IV }} \%$ & $61.07 \mathrm{a}$ & $64.43_{\mathrm{a}}$ & $56.33_{\mathrm{a}}$ & 5.02 \\
\hline \multicolumn{5}{|l|}{ Predicted Energy: } \\
\hline NEL (Mcal/ Lb. of DM) & $0.665_{\mathrm{c}}$ & $0.69_{\mathrm{b}}$ & $0.71_{\mathrm{a}}$ & 0.002 \\
\hline ME (Mcal/ Lb. of DM) & $1.10_{\mathrm{c}}$ & $1.15_{\mathrm{b}}$ & $1.19 \mathrm{a}$ & 0.0033 \\
\hline NEM (Mcal/ Lb. of DM) & $0.70_{\mathrm{b}}$ & $0.73_{\mathrm{a}}$ & $0.73_{\mathrm{a}}$ & 0 \\
\hline NEG (Mcal/ Lb. of DM) & $2.10_{\mathrm{c}}$ & $2.14_{b}$ & $2.18_{\mathrm{a}}$ & 0.001 \\
\hline DE (Mcal/ Lb. of DM) & $1.29_{\mathrm{c}}$ & $1.34_{b}$ & $1.38_{\mathrm{a}}$ & 0.0033 \\
\hline GE (MJ/Kg DM) & $1.798_{\mathrm{b}}$ & $1.799_{\mathrm{b}}$ & $1.80_{\mathrm{a}}$ & 0.001 \\
\hline \multicolumn{5}{|l|}{ Predicted Feeding values: } \\
\hline TDN \% & $64.71_{\mathrm{c}}$ & $67.03_{\mathrm{b}}$ & $68.996_{a}$ & 0.12 \\
\hline DDM \% & $70.58_{c}$ & $72.99 \mathrm{~b}$ & $75.02 \mathrm{a}$ & 0.123 \\
\hline DMI \% & $2.89_{\mathrm{c}}$ & $3.32_{\mathrm{b}}$ & $3.83_{\mathrm{a}}$ & 0.027 \\
\hline
\end{tabular}

$a, b, c$ and $d$ means within the same raw with different superscripts are significantly different at ( $p<0.05)$.

Ration (1): control 60\% CFM + 40\% RS.

Ration (2): $60 \%$ CFM+30\% RS+10\% PPPs.

Ration (3): $60 \%$ CFM+20\% RS+20\% PPPs 
Table (5): Feed cost and prices of TDN unit of the three complete rations used for fatting animals at the first stage (about $12 \% \mathrm{CP}$ ).

\begin{tabular}{lccc}
\hline Items & \multicolumn{3}{c}{ Experimental rations } \\
\cline { 2 - 4 } & Ration 1 & Ration 2 & Ration 3 \\
\hline Feed cost (P.T.)/ Kg feed & 264.0 & 260 & 256 \\
TDN, \% & 64.70 & 67.03 & 69.00 \\
Price of TDN unit (P.T.) & 408.00 & 387.90 & 371.00 \\
$\%$ of decreasing price of TDN & - & 4.39 & 9.09 \\
unit than that of control & & & \\
\hline Ration (1): Control 60\% CFM +40\%RS. & & \\
Ration (2): 60\% CFM. $+30 \%$ RS + 10\%PPPs. & & & \\
Ration (3): $60 \%$ CFM. $+20 \%$ RS + 20\%PPPs. & &
\end{tabular}

Table (6): Chemical composition and fiber fraction of rations used in experiment (2) (inclusion two levels of PPPs instead of the same levels of berseem hay).

\begin{tabular}{|c|c|c|c|c|}
\hline \multirow[b]{2}{*}{ Ingredients } & \multicolumn{3}{|c|}{ Experimental rations } & \multirow[t]{2}{*}{$\mathrm{SE} \pm$} \\
\hline & Ration 4 & Ration 5 & Ration 6 & \\
\hline $\begin{array}{l}\text { DM, \% } \\
\text { composition on dry matter, \% }\end{array}$ & 94.38 & 94.16 & 93.93 & \\
\hline Organic matter $(\mathrm{OM})$ & 91.20 & 91.33 & 91.46 & \\
\hline Ash & 8.80 & 8.67 & 8.54 & \\
\hline Crude Protein (CP) & 17.67 & 16.38 & 15.08 & \\
\hline Ether extract (EE) & 3.89 & 3.79 & 3.68 & \\
\hline Crude fiber $(\mathrm{CF})$ & 19.57 & 17.71 & 15.08 & \\
\hline Nitrogen free extract (NFE) & 50.07 & 53.45 & 57.62 & \\
\hline Non-structure carbohydrate (NSC) & 36.24 & 41.71 & 43.54 & \\
\hline \multicolumn{5}{|l|}{ Fiber fraction analysis $\%$ : } \\
\hline NDF & $33.4_{\mathrm{a}}$ & $29.45_{b}$ & $29.16_{b}$ & 0.197 \\
\hline ADF & $20.37 \mathrm{a}$ & $17.55_{\mathrm{b}}$ & $17.2_{\mathrm{c}}$ & 0.058 \\
\hline ADL & $5.62_{\mathrm{a}}$ & $4.86_{\mathrm{c}}$ & $5.12_{\mathrm{b}}$ & 0.086 \\
\hline AIA & $1.73_{\mathrm{a}}$ & $1.08_{\mathrm{b}}$ & $0.12_{\mathrm{c}}$ & 0.0093 \\
\hline Hemicelluloses & $13.03_{\mathrm{a}}$ & $11.9_{\mathrm{b}}$ & $11.96_{b}$ & 0.164 \\
\hline Cellulose & $14.75_{\mathrm{a}}$ & $12.69_{\mathrm{b}}$ & $12.08_{\mathrm{c}}$ & 0.124 \\
\hline Lignin & $3.89_{\mathrm{b}}$ & $3.78_{\mathrm{b}}$ & $5.00_{\mathrm{a}}$ & 0.088 \\
\hline NDF-cell soluble & $66.60_{\mathrm{c}}$ & $70.55_{b}$ & $70.84_{a}$ & 0.197 \\
\hline
\end{tabular}


Table (7): Dry matter digestibility determination by In-Vitro Daisy ${ }^{\mathrm{II}}$ incubator and Predicting energy and feeding values of rations used in experiment (2) (inclusion two levels of PPPs instead of the same levels of berseem hay).

\begin{tabular}{lcccc}
\hline & \multicolumn{3}{c}{ Experimental rations } & \\
\cline { 2 - 4 } Ingredients & Ration 4 & Ration 5 & Ration 6 & SE \pm \\
\hline In - vitro daisy analysis: & & & & \\
ADMDIV \% & $66.38_{\mathrm{b}}$ & $66.94_{\mathrm{a}}$ & $66.15_{\mathrm{c}}$ & 1.93 \\
TDMDIV \% & $68.58_{\mathrm{c}}$ & $71.82_{\mathrm{b}}$ & $82.27_{\mathrm{a}}$ & 1.93 \\
NDFD \% & $61.06_{\mathrm{a}}$ & $61.83_{\mathrm{a}}$ & $61.07_{\mathrm{a}}$ & \\
Predicted Energy: & & & & \\
NEL (Mcal / Lb. of DM) & $0.69_{\mathrm{c}}$ & $0.71_{\mathrm{b}}$ & $0.72_{\mathrm{a}}$ & 0 \\
ME (Mcal / Lb. of DM) & $1.15_{\mathrm{c}}$ & $1.19_{\mathrm{b}}$ & $1.20_{\mathrm{a}}$ & 0.0017 \\
NEM (Mcal / Lb. of DM) & $0.73_{\mathrm{c}}$ & $0.75_{\mathrm{b}}$ & $0.76_{\mathrm{a}}$ & 0.0029 \\
NEG (Mcal / Lb. of DM) & $0.64_{\mathrm{b}}$ & $2.19_{\mathrm{a}}$ & $2.19_{\mathrm{a}}$ & 0.0017 \\
DE (Mcal / Lb. of DM) & $1.34_{\mathrm{c}}$ & $1.38_{\mathrm{b}}$ & $1.39_{\mathrm{a}}$ & 0.0017 \\
GE (MJ/Kg DM) & $1.89_{\mathrm{a}}$ & $1.88_{\mathrm{b}}$ & $1.86_{\mathrm{c}}$ & 0.0017 \\
Predicted Feeding values: & & & & \\
TDN \% & $67.072_{\mathrm{c}}$ & $69.19_{\mathrm{b}}$ & $69.45_{\mathrm{a}}$ & 0.044 \\
DDM \% & $73.03_{\mathrm{c}}$ & $75.23_{\mathrm{b}}$ & $75.50_{\mathrm{a}}$ & 0.045 \\
DMI \% & $3.59_{\mathrm{b}}$ & $4.08_{\mathrm{a}}$ & $4.12_{\mathrm{a}}$ & 0.04 \\
\hline a, $b$, c and d means within the same raw with different superscripts are significantly different at $(p<0.05)$ & \\
Ration (4): Control 60\% CFM. + 40\%BH. & & & \\
Ration (5): 60\% CFM. + 10\%PPPs $+30 \%$ BH. & & & \\
Ration (6): 60\% CFM. + 20\%PPPs $+20 \%$ BH. & & &
\end{tabular}

Table (8): Feed cost and prices of TDN unit of the three complete rations $(4,5$ and 6$)$ used for feeding high producing animals and dairy cows (about $17 \% \mathrm{CP}$ ).

\begin{tabular}{lccc}
\hline & Experimental rations & & \\
\hline Items & Ration 4 & Ration 5 & Ration 6 \\
Feed cost (P.T.)/ Kg feed & 312 & 296 & 280 \\
TDN, \% & 67.07 & 69.19 & 69.45 \\
Price of TDN unit (P.T.) & 465.00 & 428.00 & 403.00 \\
$\%$ of decreasing price of TDN & - & 7.96 & 13.33 \\
unit than that of control & & & \\
\hline Ration (4): Control 60\% CFM. $+40 \% B H$ & & \\
Ration (5): $60 \%$ CFM. $+10 \%$ PPPs $+30 \%$ BH. & & & \\
Ration (6): $60 \%$ CFM. $+20 \% P P P S+20 \% B H$. & & &
\end{tabular}

